\title{
A Word from the President of the Society / Le mot de la Présidente de la Société
}

The relaunching of Simone de Beauvoir Studies marks a momentous milestone and the start of a new epoch in the history of the International Simone de Beauvoir Society. The relaunched Studies greatly augments the Society's global prominence and capacity to foster international and interdisciplinary scholarship related to the work of Simone de Beauvoir - a central figure in feminist studies and activism, who is among the greatest philosophers, writers, and public intellectuals of the twentieth century.

While celebrating the inaugural volume of the new Studies, as President I wish to take a moment to acknowledge the contributions of those who made this highly significant achievement possible, while also reflecting on the Society's objectives and contributions, past and present.

In 2016, at the Society's 23rd International Conference, an entirely new leadership was elected. Subsequently, the Society underwent several major organizational changes, including the breakthrough attainment of nonprofit status. Attaining this goal was critical to the Society's mission to facilitate the creation and publication of outstanding scholarship relevant to Beauvoir's work. Our nonprofit status made possible the resumed publication of our journal and our partnership with Brill, a venerated leader in academic publishing with an international reach. Under the determined direction of Editor-in-Chief Jennifer McWeeny, we have now realized this major achievement. On behalf of the Society, I want to thank Jennifer for her dedication, for her hard and excellent work. We are truly grateful! I also want to extend thanks to the journal's Editorial Team, Editorial Board, the Society's Board, Steering Committee, and membership, and everyone else who has supported and made the resumed publication of the Studies a reality.

Although the Studies' outreach, design, and management are entirely new, its roots extend back to 1981, when the Society was founded by Professors Konrad Bieber, Yolanda A. Patterson, and Jacques Zéphir at the Modern Language Association's annual convention in New York. In 1983, Dr. Patterson became the president of the organization, and Dr. Liliane Lazar assumed the responsibility of secretary-treasurer. This was also the year when Yolanda founded the Studies. For more than three decades, Yolanda and Liliane, together with dedi- 
cated members of the Society, nurtured an organization that contributed to the creation of a platform and a foundation from which current Beauvoir studies could develop and transgress toward new fields and topics. Today's research, building on the contributions of so many others, can now commence from a position where Beauvoir's status as an autonomous philosopher, feminist theorist, political thinker, and writer is finally firm and well-established. We are very grateful for the efforts of Yolanda and Liliane, and of the many authors and scholars whose works were published in the first twenty-nine volumes of the Studies, helping Beauvoir scholarship earn today's prominent and muchdeserved status.

In retrospect, what enabled such fruitful development of the organization and its journal are the three pillars of Yolanda's leadership-generosity, interdisciplinarity, and internationalism. "We have grown into a global group of scholars and admirers of Simone de Beauvoir who came together from just about the four corners of the earth to share their ideas and an admirable camaraderie which can be rare among academics," writes Yolanda in 2007. ${ }^{1}$ The organization's comradery and support provided a much-needed source of encouragement for scholars who did not have other venues for exchanges concerning their studies of Beauvoir, and inspired many to pursue and continue their research. Exchanges on a broad variety of topics and perspectives transpired in the convivial atmospheres of the Society's twenty-six international conferences to date, often culminating with publications in the Studies. "We're very proud of the variety of themes and points of view [the Studies] contains," Yolanda writes in a personal message in 2008. ${ }^{2}$ She describes the Society with the following words: "We are truly international, and very proud of it." ${ }^{3}$ The Society's legacy of international and interdisciplinary openness is a critical goal that has been maintained and supported by the organization's current leadership. Evidence of this goal is reflected in Volume 30 of the Studies, where the fruits of past and present labor are made visible in the contributors' fascinating discussions and prominent scholarship.

Today, interest in Beauvoir's work is growing at an accelerating pace, and I am certain that this high level of interest will not abate any time soon. This growth is marked by many-faceted forms of scholarship, interdisciplinarity, and

1 Yolanda Astarita Patterson, "A Word from Your Editor," Simone de Beauvoir Studies, vol. 23, 2006-2007, p. ii.

2 Yolanda Astarita Patterson, handwritten note to author sent with Simone de Beauvoir Studies, vol. 24, 2008.

3 Yolanda Astarita Patterson, "A Word from Your Editor", Simone de Beauvoir Studies, vol. 27, 2010-2011, p. 2. 
new and diverse re-readings of Beauvoir's oeuvre. By continuing to acknowledge the importance of transcending disciplinary borders and challenging national and cultural boundaries, I am confident the journal will continue to enrich and broaden the views and complexities that enlighten and inspire current scholarship on Beauvoir. Simone de Beauvoir Studies will carry, develop, and elevate excellent research on Beauvoir into new areas, serving also as an important contributor to the field of feminist studies and beyond.

La reprise des activités de la revue Simone de Beauvoir Studies $(S d B S)$ marque un jalon important et signale le début d'une nouvelle époque dans l'histoire de l'International Simone de Beauvoir Society. La relance de SdBS étend considérablement la notoriété de la Société et renforce sa capacité à favoriser les recherches interdisciplinaires et internationales ayant trait aux travaux de Simone de Beauvoir, figure centrale des études et de l' activisme féministes qui compte parmi les plus grand.e.s philosophes, écrivain.e.s et intellectuel.le.s du $\mathrm{XX}^{\mathrm{e}}$ siècle.

Si je souhaite célébrer le volume inaugural de la nouvelle mouture de la revue et souligner la contribution de ceux.elles qui en ont rendu possible la mise en œuvre, je désire également revenir sur les objectifs et les réalisations de la Société, tant passés que présents.

En 2016, lors du 23ème colloque international de la Société, une toute nouvelle équipe de direction a été élue. Par la suite, la Société a connu plusieurs changements organisationnels d'importance capitale, notamment l' obtention du statut d'organisme à but non lucratif. La réussite de ce programme était essentielle pour la mission de la Société puisqu' elle rendait possible la reprise de la publication de notre revue et la mise en place d'un partenariat avec Brill. Sous la conduite avisée de la rédactrice en chef Jennifer McWeeny, nous avons accompli ce projet majeur. Au nom de la Société, je tiens à témoigner ma reconnaissance à Jennifer pour son travail assidu et son dévouement. Je désire également remercier l'équipe éditoriale de la revue, le comité scientifique, les membres de la Société et tou.te.s ceux.elles qui ont concouru à concrétiser la relance de $S d B S$.

Bien que la conception, la gestion et la diffusion de la revue aient été entièrement renouvelées, ses racines remontent à 1981, année de la fondation de la Société par les professeurs Konrad Bieber, Yolanda A. Patterson et Jacques Zéphir lors de la convention annuelle de la Modern Language Association à New York. En 1983, Dre Patterson est devenue présidente de l'organisation et Dre Liliane Lazar secrétaire-trésorière. La même année, la première a fondé 
$S d B S$. Pendant plus de trois décennies, Yolanda et Liliane, soutenues par des membres dévouée.es de la Société, ont contribué à la création d'un organe de publication à partir duquel les études beauvoiriennes ont pu se développer, s'épanouir dans de nouveaux domaines de recherche et aborder des sujets inédits. Les travaux actuels, s'appuyant sur ce socle qu' ont solidifié les efforts de tant d'autres personnes, peuvent désormais prendre comme point de départ le statut bien établi de Beauvoir en tant que philosophe autonome, théoricienne féministe, penseuse politique et autrice polyvalente. Nous saluons le succès de l'entreprise nécessaire des nombreux auteur.trice.s et chercheur.se.s dont les travaux publiés dans les vingt-neuf premiers volumes de la revue nous ont permis d'atteindre cette position fondamentale.

Avec du recul, il apparaît clair que la progression de la Société et de sa revue est redevable à la conception tripartite prônée par Yolanda faite de générosité, d' interdisciplinarité et d' internationalisme: «Nous formons maintenant un groupe de chercheurs et de lecteurs enthousiastes de Simone de Beauvoir réunis depuis les quatre coins de la terre pour partager nos idées dans une camaraderie admirable, laquelle se rencontre rarement dans le milieu universitaire ${ }^{{ }}$, écrivait-t-elle en 2007. Ce climat positif a fourni une source d'encouragement indispensable aux chercheur.se.s qui n'avaient pas d'autres moyens de faire connaître leurs travaux sur Beauvoir et a inspiré plusieurs personnes à poursuivre leurs recherches. Les échanges portant sur une grande variété de sujets et convoquant diverses perspectives critiques se sont déroulés dans l' atmosphère conviviale des vingt-six colloques internationaux que la Société a organisés à ce jour, lesquels ont souvent donné lieu à des publications dans la revue Simone de Beauvoir Studies. «Nous sommes très fiers de la diversité des thématiques et des points de vue présentés dans la revue», écrit Yolanda dans un message personnel de 2008. ${ }^{2}$ Décrivant la Société, elle se réjouit avec raison: «Nous avons atteint un statut international dont nous pouvons nous enorgueilir ${ }^{3}$.» L'ouverture interdisciplinaire et internationale de la Société, une visée que maintient l'équipe de direction actuelle et qui se reflète dans le volume inaugural de la nouvelle mouture de $S d B S$, alimente un dialogue passionnant et débouche sur des travaux de recherche remarquables.

1 Yolanda Astarita Patterson, «A Word from Your Editor», Simone de Beauvoir Studies, vol. 23, 2006-2007, p. ii, traduit par Claudia Bouliane.

2 Yolanda Astarita Patterson, note manuscrite envoyée à l' auteure avec sa livraison personnelle du volume 24 (2008) de Simone de Beauvoir Studies, traduit par Claudia Bouliane.

3 Yolanda Astarita Patterson, «A Word from Your Editor», Simone de Beauvoir Studies, vol. 27, 2010-2011, p. 2, traduit par Claudia Bouliane. 
Aujourd' hui, l'intérêt pour l'œuvre de Beauvoir continue de grandir, et cela ne cessera de sitôt. Cette croissance est marquée par de nouveaux travaux d'érudition aux angles d'investigation multiples et interdisciplinaires qui promeuvent des relectures originales de ses écrits. Par son souci constant de transcender les frontières culturelles et nationales comme de se situer au-delà des limites entre les domaines de recherche, la revue persévérera dans sa mission d'élargir et de complexifier la vision qui éclaire et inspire les recherches actuelles sur Beauvoir. La revue Simone de Beauvoir Studies poursuivront cette noble tâche et ouvriront la voie à de nouvelles approches critiques, apportant une contribution cruciale aux études féministes de même qu'à beaucoup d' autres champs d' exploration contemporains.

\author{
Tove Pettersen \\ University of Oslo \\ tove.pettersen@stk.uio.no
}

